Ilija Mikić

Archaeological Institute, Belgrade

mikicilija82@gmail.com
UDK 572.71:577.2"653”(497.11)

Original research article

Received: June 04, 2010

Accepted: August 02, 2010

\title{
EPIGENETIC TEST ON MEDIEVAL SKULLS FROM VINČA
}

\begin{abstract}
During the past fifty years, more attention was paid to epigenetics as an addition to morphometry, especially in bio-physical anthropology. In Serbia, first papers of this kind, as an addition to classical anthropological analyses of skeletons from anthropological sites appeared during the seventies of 20th century. Still, our experiences are insignificant in this field of research. In our anthropological literature, there are only a few papers. In this paper, only the results of epigenetic tests conducted on fifty preserved skulls from the mediaeval cemetery in Vinča are presented. During several campaigns in Vinča, some 1000 skeltons were excavated, but they were not preserved and well kept. The group of only fifty wholy preserved skulls remained, which was kept at the Dental faculty, but now kept at the Philosophical Faculty in Belgrade. The results of their epigenetic test are presented in table 1 and discussed within the integral part of this paper.
\end{abstract}

Key words: Biophysical anthropology, Middle Ages, age, sex, epigenetic variations.

\section{INTRODUCTION}

At the end of the sixties of 20th century, in biology, and especially in biophysical anthropology, more attention was paid to skeletal characteristics which were not continuously present, but were varying from one individual to another or from one population to another. The following terms were used: variant, variety, variable, data, marks, dispositions. The most frequent adverbs appearing were: anatomic, abnormal, varying non-metric, morphological, quazi-continuing, incontinuous, discontinuous, discontinuous variables, non-adjusted, discrete, little/lesser. But there is also a smaller number of marks which can be described with the following terms: malformation, anomaly, heterotipy and discreta. Still, in time, some of the terms prevailed: anatomic variations, epigenetic and non-metric features. In time, it also turned out that pathological changes

* The article results from the project: Viminacium, Roman city and military legion camp - research of material and non material of inhabitants by using the modern technologies of remote detection, geophysics, GIS, digitalisation and $3 D$ visualisation (no 47018), funded by Ministry of Education and Science of the Republic of Serbia. 
on bones cannot be ascribed to the complex of these characteristics. The best example is Cribra orbitalia, which was proved to be caused by a specific disease (Hengen 1971; Grupe 1995). Even after this, Cribra orbitalia still appears on epigenetic lists, without taking into consideration that it actually has its rightful place in quantitative paleopathology (Reinhard and Rösing 1985).

The importance of epigenetic elements/ anatomic variations is shows in a possibility to broaden analyses of similarities between different population groups, but also their individuals, as an addition to osteometric values. Contrary to metric characteristics on fragmented osteological material, the "non-metric elements" have their advantage, because they enable a more reliable determination of sex and skeletal age, due to differencies in development. There is a well-known example of a skeletal series Mikulčice, on which A. Czarnetzki already in 1972 recognized a very extreme difference in frequency of numerous epigenetic elements between men and women, even recommending their separate observation and interpretation (Czarnetzki 1972).

One should add that genesis of epigenetic elements is heterogenous and there is only few hundreds of them. The greatest part is genetically conditioned and follows polygenetic inheritance (for example blood and nerve supply). The second group was undoubtfully gained during one's lifetime and expresses specific activities of individuals and groups (mostly on post-cranial skeleton). The third group is a result of common activities of genetic dispositions and outer influences. There are inlayed bones in skull sutures (special nuclei of ossification), for which it is well-known that their number varies from one population to another. On the other side, for example at artificially deformed skulls, epigenetic elements can be caused (Sjovold 1984).

It should be mentioned that a frequent term for this kind of skeletal characteristics among the English-speakers is "Discreta traits" and a sim- ple "Discreta" among the German-speakers, although the most commonly used term in literature actually is - Epigenetic variation.

\section{MATERIAL}

The analyzed skulls come from graves excavated during the archaeological research of Vinča, conducted between 1978 and 1982 by G. Vujović-Marjanović and her team (National Museum, Belgrade). This cemetery was used in the period from 8 th to 17 th century and the anthropologial material is very poorly preserved. The main reason is an intense usage of this cemetery and digging new graves into the already existing older ones, as well as agricultural usage of the upper soil layers on this site (Vujović-Marjanović 1982, 91-97).

Since after the archaeological excavation such a large amount of medieval osteological material could not be preserved and kept, only fifty skulls were sorted out, chosen because of their state of preservation. They were handed over to the staff of the Faculty of Stomatology for certain research, but recenly, they are kept at the Faculty of Philosophy in Belgrade, where the epigenetic test was undertaken.

The fifty skulls belong to a broad chronological span. During the research, it was determined that 28 skulls belonged to men and 22 to women. It meant that $56 \%$ were male and $44 \%$ female skulls. ${ }^{1}$ Considering individual biological age, only one skeleton belonged to the juvenile age, 19 to the adult group, not more than 25 to the mature group and the remaining five to the oldest group (senilis).

In order to show at least basic features of the morphological structure, basic skull index was calculated and represented (the index of cranial

1 According to an oral information from Ž. Mikić, this would approximately correspond to $10 \%$ of all the adult individuals from the excavated part of the cemetery of totaly about 750 graves and about 1000 skeletons. 
width and length), which showed great variety. damaged, they could have not be specified.

More precisely, 15 skulls belonged to the dolicho-

All data are given in the following over-

cranial type, 11 to the mesaticranial and 22 to the view:

brachycranial type. Since two skulls were partly

\begin{tabular}{|c|c|c|c|}
\hline Grave number & Sex & Age & $\begin{array}{l}\text { Longitudinal } \\
\text { width index }\end{array}$ \\
\hline 8 & female & maturus & 75,14 \\
\hline 69 & male & adultus & 73,62 \\
\hline 131 & male & maturus & 72,16 \\
\hline 133 & female & maturus & 76,27 \\
\hline 153 & male & maturus & 73,68 \\
\hline 158 & male + infant & maturus & 77,32 \\
\hline 159 & male & maturus & 71,72 \\
\hline 162 & male & maturus & 75,26 \\
\hline 192 & male & maturus & 69,61 \\
\hline 195 & male & adultus & 82,35 \\
\hline 197 & male & maturus & 89,87 \\
\hline 214 & male & maturus & 76,34 \\
\hline 230 & male + infant & maturus & 87,02 \\
\hline 235 & male & senilis & 80,25 \\
\hline 261 & female & adultus & 81,92 \\
\hline 267 & female & adultus & 78,37 \\
\hline 270 & female & adultus & 74,57 \\
\hline 280 & female & adultus & 81,92 \\
\hline 296 & female & maturus & ? \\
\hline 309 & male & adultus & 82,35 \\
\hline 322 & male & maturus & 90,64 \\
\hline 337 & male & maturus & 88,57 \\
\hline 338 & female & adultus & 73,68 \\
\hline 360 & male & senilis & 75,67 \\
\hline 366 & male + infant & adultus & 88,62 \\
\hline 368 & female + infant & adultus & 81,35 \\
\hline 371 & male & maturus & 83,42 \\
\hline 374 & male & maturus & 78,21 \\
\hline 383 & male & adultus & 89,09 \\
\hline 399 & female & adultus & 83,62 \\
\hline 400 & female & adultus & $?$ \\
\hline
\end{tabular}




\begin{tabular}{|l|c|c|c|}
\hline 405 & male & adultus & 83,61 \\
\hline 419 & male & maturus & 72,63 \\
\hline 439 & female & maturus & 82,48 \\
\hline 447 & male & senilis & 73,57 \\
\hline 450 & male & maturus & 85,71 \\
\hline 465 & female & maturus & 74,44 \\
\hline 455 & male +infant & adultus + juvenilis & 93,41 \\
\hline 478 & male & senilis & 90,62 \\
\hline 485 & female & maturus & 76,08 \\
\hline 491 & male & adultus & 84,61 \\
\hline 510 & female & maturus & 86,22 \\
\hline 518 & female & maturus & 67,57 \\
\hline 519 & female & maturus & 79,77 \\
\hline 524 & male & adultus & 74,45 \\
\hline 530 & male & adultus & 73,93 \\
\hline 531 & female & adultus & 80,11 \\
\hline 534 & male & juvenilis & 71,35 \\
\hline 541 & male & maturus & 73,62 \\
\hline 542 & male & senilis & 74,46 \\
\hline 552 & male + infant & juvenilis & 70,22 \\
\hline & & & \\
\hline & & & \\
\hline
\end{tabular}

Since all of the examined skeletons belong to individuals whose growth and development were complete and since they possess an extremely heterogenous morphostructure, they were determined as an anthropological collection.

\section{METHOD}

The methodology applied on the anthropological collection from medieval Vinča is twofold. The first part is the so called standardized methodology of an anthropological study of skeletons, concearning sex, age and morphometry (connected to the calculation and categorizing of cranial length and width). The second part is the epigenetic analysis. The results gained need to be presented separately.
The results gained after the standardized anthropological method were already presented in the previous chapter (about material), by applying the following standards: for determining sex after elements present on skulls, criteria were applied defined by D. Ferembach, I. Schwidetzky and M. Stloukal. ${ }^{2}$ For determining individual age only by examining skulls, combined methods were applied, since of all the crietria, only two were at our disposal - separation of superficial teeth levels and the joining of skull sutures (Lovejoy 1985; Olivier 1973.). ${ }^{3}$

2 In front of the group of about forty biophysical anthropologists from Europe, the United States and Canada (Ferembach, Schwidetzky i Stloukal 1980).

3 Individual age was added to the following categories: juvenilis/subadultus (19/22 years), adultus (from about 20 to about 40 years of age), maturus (from 40 to 60 years) and senilis (over 60 years of age). 
Two basic skull measurments needed for the mentioned index - the greatest skull length (the distance between the measuring points G-OP) and the greatest width (the distance between even points EU-EU) were measured after R. Martin's definitions (Martin 1928), i. e. after reformed instructions of W. Bass (Bass 1971).

For the needs of the epigenetic test, the adequate methodological literature was consulted, in order to make the best possible choice of served through a special process and not dug out of the soil. Because of that, the number of epigenetic elements mentioned in the literature was reduced to 25 and specified within the epigenetic notification-paper applied in this test. It includes the most frequently preserved epigenetic elements on archaeologically excavated skulls. These are the following epigenetic elements, next to the column for special remarks (in order to mark the specifics of each skull):

\begin{tabular}{|c|c|}
\hline 1. Os Incae/Os Lambdae & 14.Os epiptericum \\
\hline 2. Ossa suturae lambdoidae & 15. Torus auditorius \\
\hline 3. Linea nuchae suprema & 16. Foramen spinosum \\
\hline 4. Os intersuturale parietalis & 17. Foramen palatinum \\
\hline 5. Os Asterion & 18. Foramen ovale \\
\hline 6. Foramen mastoideum exsutural & 19. Tuberculum praecondilaris \\
\hline 7. Condilus occipitalis dubl & 20. Foramen Huschke \\
\hline 8. Os Bregmaticum & 21. Canalis postcondilaris \\
\hline 9. Foramen parietale & 22. Metopism \\
\hline 10. Ossa suturae coronalis & 23. Foramen supraorbitale \\
\hline 11.Foramen zygomaticofacialis & 24. Incisura/sulcus supraorbitalis \\
\hline 12. Foramen infraorbitale & 25. Os zygomaticum partitum \\
\hline 13. Foramen frontale & 26. Special acknowledgments \\
\hline
\end{tabular}

elements which can be preserved on anthropological material from archaeological sites. In this sense, the most helpful were the already wellknown publications (ex. Berry and Berry 1967; Czarnetzky 1971; Hauser and De Stefano 1989), as well as working material of B. Kaufmann (Anthropological Institute, Basel), which was put at our disposal and which is more voluminous than the previously published book (Kaufmann 1986).

It was imidiately noticed that, due to poor state of preservation of skeletal material from archaeological sites, out of several hundreds of epigenetic elements, most of them cannot actually be studied. It is quite contrary to material from anatomic collections and institutes, which is pre-
Within the notification-papers, all the details were named connected to each element, like oscillations, dimensions etc. According to the sequence in which the elements were given, it was most practical to begin the observation with the posterior projection of each skull, then the vertical, both of the lateral, basilar and at the end the facial projection.

Apart from these epigenetic elements, in notification-papers there were also the grave numbers, i.e. skull, gender, individual age, the value of longitudinal-latitudinal index of each skull, as well as the date of evaluation. Due to their volume, epigenetic notification-papers cannot be incorporated into an anthropological paper of this kind. 


\section{RESULTS}

Since the data concerning gender, age and basic index of each out of fifty skulls from the medieval anthropological collection from Vinča were already given within the chapter about the material itself, one can now only present precise epigenetic results gained. They are shown within the following table:

Table 1 : Vinča - the number and percent of all frequencies of epigenetic variations specified after sex.

\begin{tabular}{|c|c|c|c|}
\hline Epigenetic element & Total & Men & Women \\
\hline & $+/ \mathrm{n}=\%$ & $+/ n=\%$ & $+/ \mathrm{n}=\%$ \\
\hline Os Incae & $4 / 50=8 \%$ & $1 / 28=2 \%$ & $3 / 22=6 \%$ \\
\hline Os Lambdae & $9 / 50=18 \%$ & $5 / 28=10 \%$ & $4 / 22=8 \%$ \\
\hline Lambda sutura & $23 / 50=46 \%$ & $11 / 28=22 \%$ & $12 / 22=24 \%$ \\
\hline Linea nuche suprema & $14 / 50=28 \%$ & $7 / 28=14 \%$ & $7 / 22=14 \%$ \\
\hline Os intersuturale parietalis & $2 / 50=4 \%$ & $0 / 0$ & $2 / 22=4 \%$ \\
\hline Os Asterion & $12 / 50=24 \%$ & $6 / 28=12 \%$ & $6 / 22=12 \%$ \\
\hline Foramen Mastoideum Exsutural & $23 / 50=46 \%$ & $16 / 28=32 \%$ & $7 / 22=14 \%$ \\
\hline Condilus Occpitalis Dubl & $3 / 50=6 \%$ & $2 / 28=4 \%$ & $1 / 22=2 \%$ \\
\hline Os Bregmaticum & $0 / 0=0 \%$ & $0 / 0=0 \%$ & $0 / 0=0 \%$ \\
\hline Foramen parietale & $19 / 50=38 \%$ & $9 / 28=18 \%$ & $10 / 22=20 \%$ \\
\hline Ossa Suturae coronalis & $2 / 50=4 \%$ & $1 / 28=2 \%$ & $1 / 22=2 \%$ \\
\hline For zygomaticofaciale & $33 / 50=66 \%$ & $20 / 28=40 \%$ & $13 / 22=26 \%$ \\
\hline Foramen infraorbitale & $44 / 50=88 \%$ & $28 / 28=56 \%$ & $16 / 22=32 \%$ \\
\hline Foramen frontale & $9 / 48=18,75 \%$ & $4 / 26=8,33 \%$ & $5 / 22=10,4 \%$ \\
\hline Os Epiptericum & $9 / 50=18 \%$ & $4 / 28=8 \%$ & $5 / 22=10 \%$ \\
\hline Torus auditorius & $2 / 47=4,25 \%$ & $2 / 25=4,25 \%$ & $0 / 0=0 \%$ \\
\hline Foramen spinosum & $0 / 0=0 \%$ & $0 / 0=0 \%$ & $0 / 0=0 \%$ \\
\hline Foramen palatinum & $\begin{array}{l}4 / 4 \text { poorly pre- } \\
\text { served }\end{array}$ & & \\
\hline Fotamen ovale & $23 / 26=88,5 \%$ & $15 / 19=57,7 \%$ & $8 / 9=30,8 \%$ \\
\hline Tuberculum praecondylare & $\begin{array}{l}1 / 4 \text { poorly pre- } \\
\text { served }\end{array}$ & & \\
\hline Foramen Huschke & $\begin{array}{c}6 / 9 \text { poorly pre- } \\
\text { served }\end{array}$ & & \\
\hline Canalis postcondilaris & $12 / 33=36 \%$ & $8 / 14=24 \%$ & $4 / 9=12 \%$ \\
\hline Metopism & $5 / 5=10 \%$ & $2 / 28=4 \%$ & $3 / 22=6 \%$ \\
\hline Foramen supraorbitale & $14 / 49=28,57 \%$ & $5 / 28=10,2 \%$ & $9 / 21=18,36 \%$ \\
\hline Incisura supraorbitale & $26 / 50=52 \%$ & $15 / 28=30 \%$ & $11 / 22=22 \%$ \\
\hline Sulcus supraorbitalis & $31 / 50=62 \%$ & $19 / 28=38 \%$ & $12 / 22=24 \%$ \\
\hline
\end{tabular}


The table 1 shows that there were no specifications on the collection of medieval skulls which could be notified under nr. 26. Still, due to great frequency of elements like Os Incae and Os Lambdae they can be separated into $1 / \mathrm{a}$ and $1 / \mathrm{b}$. The same is with Incisura supraorbitalis (24/a) and supraorbital foramen $(24 / b)$. The reason is their position on the skull itself.

It should also be explained that the percentage was calculated according to the number of skulls examined for each epigenetic element separately. It was not calculated when the state of preservation of specific skull parts was extremely poor and only in cases of less than ten observations. It was shown with three epigenetic variations on specific skull parts: foramen palatinum (nr. 17 could have been observed on four skulls), Tuberculum praecondilaris on four skulls), as well as Foramen Huschke (nr. 20 - observed on maximum nine skulls).

Table 1 did not include epigenetic variations on madibulas. The reason is that in some cases the mandibulas were missing or in a very poor state of preservation.

\section{DISCUSSION AND CONCLUSION}

The collection of fifty skulls represents a choice of best preserved skulls from the medieval necropolis of Vinča. They were excavated during the archaeological research between 1978 and 1982 and they represent about $10 \%$ of all the adult individuals discovered on the studied part of this necropolis. For a short period of time, they were given to the Faculty of Stomatology in Belgrade and they were recently handed over to the Faculty of Philosophy. In 2010, they were examined there by undergoing an epigenetic test as a part of a complex anthropological analysis. All the other skulls are unfortunately lost.

If one returns to table 1 , it can be seen that Os Incae was observed on one male and three fe- male skulls. That is a rather high frequency concerning the number of skulls studied, but their forms do not completely fit into schemes given by ex. Kanadoff and Mustafov (Kanadoff and Mustafov 1970) or Hauser and De Sefano (Hauser and De Stefano 1989).

Os lambdae is situated in the same, occipital skull zone, as well as the Os Incae, pars Incodiae squamose occipitalis and sutura Mendoza. In the studied skull group, it was observed on five male and four female skulls. Its total frequency is $18 \%$, while their forms are rather difficult to systematize according to the already existing and observed forms named in literature. This should be understood as a very broad individual variation.

The bones inlayed into the lambda sutura (Ossa suturae lambdoidae) were practically present on half of the skulls - 46\% (11 male and 12 female skulls). Their total number is 122 and they are very hard to systematize or categorize, since they are never bigger than $20 \mathrm{~mm}$.

Linea nuchae suprema is not especially outraging, but it was observed on seven male and seven female skulls, $28 \%$ in total.

Os intersuturale parietalis was observed on only two female skulls. It is of small dimensions and on both of the skulls, it was located on the right side.

Os asterion was observed on six male and six female skulls, although it was examined on the whole collection. Its appearance is rather frequent and it appears on one as well as on both sides.

Exsutural foramen mastoideum was discovered on 16 male and seven female skulls. It can be determined as frequent, since it appears on $46 \%$ of all the skulls.

Condilus occipitalis dubl was noticed only on two male and one female skull. Its frequency is low, especially because it was not discovered in an extremely doubled form.

Os bregmaticum, as a specific ossification nucleus, was not found on any of the examined skulls. 
Foramen parietale was also examined and detected on nine male and ten female skulls, which makes the total of $38 \%$.

Ossa suturae coronalis include small bones inlayed into the skull sutura named above. They were discovered only on one male and one female skull, always on the right side. On the male skull, there are several of them, but they are all of very small dimensions.

Foramen zygomaticofacialis was found on 20 male and 13 female skulls, meaning that its frequency in total measures $66 \%$. The total number of such openings was $82 \%$, showing that some were doubled (everything was noted in the named notification-papers).

Foramen infraorbitale is an opening through which runs an important facial vein. It was found on 28 male and 16 female skulls, which shows the greatest frequency of totaly $88 \%$.

Foramen frontale is a passage for a branch of the same facial vein, which was observed on nine skulls - four male and five female skulls. It is present on $18,7 \%$ of the skulls.

Os epiptericum was examined on all of the 50 skulls, but it was found on four male and five female skulls, $18 \%$ in total. Their locations, shapes and dimensions are very different, which was precisely noted in epigenetic notification-papers.

Due to partial preservation, torus auditi$v u s$ was examined on only 47 skulls. It was found only on two male skulls, which makes $4,2 \%$.

Foramen spinosum was examined on the whole collection, but it was not found.

Foramen paltinum is anothetr epigenetic variation which was difficult to trace, due to the poor state of preservation. In this case, it was found only on four skulls - one male and three female ones.

Foramen ovale was examined on 26 , but found only on 23 skulls. As an important opening on the skull's base, it is present on $88,5 \%$ of the examined skulls (26) - 57,7\% belongs to male and $30,8 \%$ to female skulls.
Tuberculum praecondylare was examined on four skulls, but found only on one female skull. It can be concluded that it highly depends on the state of presevation of the osteological material.

Foramen Huschke is again highly dependent on the state of preservation of anthropological finds. It was named after its finder, A. Huschke. It was examined on nine skulls and discovered only on six of them.

Canalis postcondylaris represents a passage for a big blood vessel on skull's base and it was examined on 33 skulls. It was found on 12 of them $(36 \%)$ - eight male (24\%) and four female ones $(12 \%)$.

Metopism was examined on all of the 50 skulls. It was discovered on two male and three female skulls, which makes $10 \%$ in total. On all of the skulls it was present in its whole length.

Fisura metopica was not noticed at all.

Foramnen supraorbitale was examined on 49 skulls. It was found in 14 cases, i.e. on five male and nine female skulls. In total, it makes 28 , $6 \%$, actually $10,2 \%$ and $18,4 \%$.

Incisura supraorbitalis was examined on all of the 50 skulls, but it was found on 26 of them (52\%). They include 15 male (30\%) and $11 \mathrm{fe}-$ male skulls $(22 \%)$.

Sulcus supraorbiralis was examined on the whole collection on medieval skulls from Vinča. It was discovered on 31 of them (62\%), out of which there are 19 male (38\%) and 12 female skulls (24\%).

Os zygoomaticum partitum, as the last in the selection of the most commonly preserved epigenetic elements, was examined on the whole collection, but it was found on none of the skulls.

$* * *$

Due to poor state of preservation, the author faced several problems during his research. First of all, he had a group of fifty skulls chosen because of their state of preservation. Since the anthropological series of medieval Vinča was not 
completely published, certain value shoud be given to this skull collection and all of the necessary anthropological analyses should be undertaken.

The question of terms also had to be solved. The best example is foramen Huschke, which is also named foramen acusticum Huschke and foramen tympanica. The first term was chosen, just like the original one, after A. Huscke.

It turned out that the number of pathological changes observed as epigenetic elements is growing. The case with cribra orbitalia was already explained. Still, the appearance of exostases in the outer auditory canal (Porus acusticus externus) is a result of pathological changes, so it cannot be observed as an epigenetic element, which was already shown on the anthropological material from Sirmium (Miladinović-Radmilović 2010, 137-145). That means that torus auditivus shoud not be considered as epigenetics, but as quantitative paleopathology.

No matter that our experience in the field of epigenetic analyses is insignificant, it includes only skeletal series. Since in this case one is dealing with a collection of medieval skulls chosen after their state of preservation, which in no case can represent an anhropology series, any kind of comparing would not give adequate results. After all that was said, it is certain that a specific systematization and standardization in this field of research would be highly welcome.

\section{BIBLIOGRAPHY}

Bass,W. M. 1971

Human osteology, Missouri: Archaeological Society.

\section{Berry, A. C. and Berry, R. J. 1967}

Epigenetic variation in the human cranium, Journal of Anatomy 101:361-379.

\section{Czarnetzki, A. 1971}

Epigenetische Skelettmerkmale im Populationsvergleich, Z. Morph. Anthrop. 63 (2):238-254.

\section{Czarnetzki, A. 1972}

Epigenetische Skelettmerkmale im Populationsvergleich, Z. Morph. Anthrop. 64 (2):145-158.

\section{Ferembach, D. Schwidetzky, I. and Stloukal, M. 1980}

Recomodation for Age and Sex Diagnoses of Sceletons, Journal of Human Evolution 9:517549.

\section{Grupe, G. 1995}

Zur Ätiologie der Cribra orbitalia, Z. Morph. Anthrop. 81 (1):125-137.

\section{Hauser, G. and de Stefano, G. F. 1989}

Epigenetic Variants of human Skull, Stuttgart: E. Schweizbart'sche Verlagsbuchhandlung.

Hengen, O. P. 1971

Cribra orbitalia-pathogenesis and probable etiology, Homo 22: 57-75.

\section{Lovejoy, C. O. 1985}

Dental Wear in the Libben Population, Amer. $J$. Phys. Anthrop. 69: 47-56.

\section{Kaufmann, B. 1986}

Eine Ähnlichkeitsanalyse anhand kombinierten metrischer und nichtmetrischer Befundgruppen, 
In: B. Hermann (Eds.): Inovative Trends in der prähistorischen Antropologie, Berlin: Berliner Ges. Anthrop. Ethnol. Urgesch.:63-66.

\section{Martin, R. 1928}

Lehrbuch der Anthropologie in systematischer Darstellung, Jena: Gustav Fischer.

Martin, R. and Saller, K. 1959

Lehrbuch der Anthropologie, 3. Aufl. Von K. Saller, Bd. II, Stuttgart: Gustav Fischer.

Miladinović-Radmilović, N. 2011

Exostoses of the external Auditory canal, Starinar LX / 2010: 137-145.

Olivier, G. 1973

Osteologie et orthologie, La sqelette axial, Paris: Vigot Freres.

\section{Reinhard R. and Rösing, F.W 1985}

Ein Literaturüberblick über Definitionen diskreter Merkmale / anatomischer Varianten am Schädels des Menschen, Ulm: Universitat Ulm.

\section{Sjovold, A. 1984}

A perort on heritability of some cranial and non metric Traits, In: Ven Verk et al., Multivariante statistics in Physical Anthropology 49, Dodrecht: Riedel: 223-246.

\section{Vujović Marjanović, G. 1982}

Vinča, Beli Breg - srednjovekovna nekropola, Arheološki pregled 23: 91-97.

\section{REZIME EPIGENETSKI TEST ANTROPOLOŠKE KOLEKCIJE LO- BANJA SREDNJOVEKOVNE VINČE}

\author{
KLJUČNE REČI: BIOFIZIČKA ANTROPOLOGIJA, SRED- \\ NJI VEK, INDIVIDUALNA STAROST, POL, EPIGENETSKE
} VARIJACIJE.

Krajem šezdesetih godina XX veka u biologiji, a posebno u biofizičkoj antropologiji, počinje da se obraća značajna pažnja na karakteristike skeleta koje nisu kontinuirano prisutne, nego variraju kako od individue do individue, isto tako od populacije do populacije. Ovaj kompleks karakteristika je u međuvremenu imenovan brojnim nazivima. To su sledeći imenski termini: varijante, varijacije, varijable, podaci, oznake, dispozicije. Kao najčešći pridevski termin u literaturi se pojavljuju sledeći izrazi: anatomski, anormalni, odstupajući, nemetrički, morfološki, kvazi kontinuirani, nekontinuirani, diskontinuirano varijabilni, neadaptivni. Međutim, postoji još jedan mali broj oznaka, koji se može podvesti pod sledeće termine: malformacija, anomalija, heterotipija i diskreta. Ali, vremenom se težište usmerilo na izraze kao što su anatomske varijacije, epigenetika i nemetričke osobine čoveka. Takođe, vremenom se uvidelo da su kompleksu ovih karakteristika pripisivane patološke promene na kostima, kao što su npr. Cribra orbitalia i pojava egzostoza u spoljnom slušnom kanalu. Pomenimo da se slične pojave vremenom ispravljaju, a epigenetskih elemenata na lobanji i postkranijalnom delu skeleta čoveka ima nekoliko stotina. Njihov značaj se ogleda u mogućnosti proširenja analize sličnosti između različitih grupa stanovništva, ali i njenih pojedinaca, kao dopuna osteometrijskim vrednostima. Nasuprot metričkim karakteristikama, ove nemetričke pokazuju specifičnosti u razvoju, kako na ontogenetskom, tako i na poligenetskom planu. Najveći broj epigenetskih elemenata je genski uslovljen i sledi poligenetsko nasleđivajnje, kao što su npr. specifičnosti u 
prokrvljenosti i inervaciji tela.

Naša iskustva na epigenetskom planu su nevelika.

U našoj antropološkoj literturi prisutan je mali broj radova o epigenetici, gde ona ulazi u sastav standardne antropološke analize skeleta. Odvojeni naslovi su kod nas izuzetno retki.

Oko 1980. godine u nekoliko arheoloških kampanja na Vinči je iskopavana srednjevekovna nekropola. Tom prilikom je arheološki istraženo oko hiljadu skeleta, koji nisu svi pronađeni u individualnim grobovima. Oni ne pripadaju najstarijoj i najmlađoj fazi sahranjivanja, tako da se mogu datovati u vremensko razdoblje između XI i XV veka. Nažalost, svi ovi skeleti nisu u celini antropološki publikovani, niti su svi mogli biti deponovani. Grupa od 50 najbolje očuvanih lobanja se doskora nalazila na Stomatološkom fakultetu u Beogradu, a odnedavno je na Filozofskom fakultetu u Beogradu, gde je 2010. godine i objavljena njihova epigenetska analiza.

S obzirom da se radi o grupi lobanja koja je izabrana po kriterijumu očuvanosti, posmatrana je kao kolekcija, pošto ona nikako ne predstavlja antropološki seriju. Sam epigenetski test za ovu kolekciju srednjovekovnih lobanja iz Vinče je prvo podrazumevao pripremu epigenetskih zapisnika, koji je obuhvatio 25 elemenata koji su najčešće očuvani na skeletnom materijalu poteklom sa arheoloških nalazišta. Njihov izbor se decidno može videti na tabeli 1 .

Rezultati testa su prikazani na tabeli $1, \mathrm{~s}$ tim što obuhvataju prisustvo određenog epigenetskog testa, broj lobanja na kojima je posmatran, kao i procentualnu vrednost (u odnosu na broj opservacija). U integralnom delu priloga (na engleskom jeziku) dobijeni rezultai su objašnjeni i prodiskutovani, a u smislu zaključka autor je izneo da poređenje naših inače skromnih epigenetskih rezultata sa ovom kolekcijom lobanja nije svrsishodno, s tim što bi određena sistematizacija i standardizacija na ovom planu u našoj praksi svakako dobrodošla. 